\title{
Gene Expression Profiling of a Compatible Interaction Between Douglas-Fir and the Root Rot Fungal Pathogen Phellinus sulphurascens
}

\author{
M. A. Islam, Rona N. Sturrock, and Abul K. M. Ekramoddoullah
}

Natural Resources Canada, Canadian Forest Service, Pacific Forestry Centre, 506 West Burnside Road, Victoria, BC, V8Z 1M5, Canada. Accepted for publication 21 December 2012.

\begin{abstract}
Islam, M. A., Sturrock, R. N., and Ekramoddoullah, A. K. M. 2013. Gene expression profiling of a compatible interaction between Douglas-fir and the root rot fungal pathogen Phellinus sulphurascens. Phytopathology 103:583-593.

Douglas-fir (DF) (Pseudotsuga menziesii) is one of the largest and most economically important coniferous species in western North America. Its productivity is greatly affected by the root rot fungus Phellinus sulphurascens Pilát. Evidence of resistance by DF to fungal root pathogens such as $P$. sulphurascens has been reported but mechanisms of resistance in this compatible pathosystem are not yet known. To better

lar level, we selected 12 diverse plant genes already identified as defenserelated from a cDNA library constructed using root tissues from $P$. sulphurascens-infected DF seedlings. Using quantitative reverse-transcriptase polymerase chain reaction on infected DF root samples collected at five different time points after inoculation, we found that $P$. sulphurascens infection significantly elevated expression of the 12 selected genes. In most cases the highest expression level was recorded within 2 to 3 days after inoculation. The constructed cDNA library, which is enriched with defense-related host genes and a number of fungal genes, will continue to serve as a useful resource for future larger-scale gene discovery and functional research on the $P$. sulphurascens and DF pathosystem.
\end{abstract} understand the DF-P. sulphurascens interaction, especially at the molecu-
In western North America, productivity of the economically important coniferous species Douglas-fir (DF) (Pseudotsuga menziesii (Mirb.) Franco) is significantly impacted by laminated root rot (LRR), caused by the pathogenic fungus Phellinus sulphurascens Pilát. LRR can decrease stand volumes by as much as $70 \%$ on infected sites (19). P. sulphurascens attacks and kills trees of all ages and also affects several other coniferous species $(4,35,52)$. In $P$. sulphurascens-infected stands, the disease spreads from inoculum sources (i.e., roots of infected stumps or of infected dead or living whole trees) to healthy host roots by way of vegetative, ectotrophic mycelia (52). The fungus initially penetrates bark tissues of host roots and then colonizes and kills phloem and cambial tissues as it enters and initiates decay in the xylem (59). Initial investigation of pathogenicity-related genes in $P$. sulphurascens has identified genes encoding potential pathogenicity factors such as the cell-wall-loosening protein expansin and cell-wall-degrading enzymes such as endogluconase, pectinesterase, and polysaccharide deacetylase. Other genes identified in $P$. sulphurascens and generally considered important to the virulence of phytopathogenic fungi include those coding for tetraspanins, hydrophobins, metalloproteases, and a few small, unknown, putatively secreted proteins (H. L. Williams, R. N. Sturrock, M. A. Islam, C. Hammett, A. K. M. Ekramoddoullah, and I. Leal, unpublished data). Evidence of resistance by coastal DF to $P$. sulphurascens and by interior DF to another basidiomycetous root pathogen, Armillaria ostoyae (Romagn.) Herink, has been described through field observation (8) and by way of empirical testing $(10,50)$ but mechanisms of resistance in these compatible pathosystems are not yet known.

Corresponding author: M. A. Islam; E-mail address: aislam@nrcan.gc.ca

* The $\boldsymbol{e}$-Xtra logo stands for "electronic extra" and indicates that the online version contains one supplemental figure.

http://dx.doi.org/10.1094/PHYTO-04-12-0086-R

(c) 2013 Her Majesty the Queen in right of Canada, Natural Resources Canada, Canadian Forest Service
Plants are known to activate a wide range of both preformed and induced defense systems (57) to initiate resistance mechanisms against pathogen invasion $(20,21,28)$. Contemporary research on molecular aspects of host-pathogen interactions indicates that inducible defense responses in plants are triggered by two levels of a microbial recognition mechanism. At the first level, the recognition is initiated by conserved microbial or pathogen molecules known as pathogen-associated molecular patterns (PAMPs). PAMP-triggered immunity (PTI) via pattern recognition receptors is the most important key to plant innate immunity. At the second level of recognition, most plants have evolved effector-triggered immunity (ETI) via cytoplasmic resistance (R) proteins and defense-related proteins to recognize particular effectors $(12,54,65,66)$. Recognition of microbial effectors results in the upregulation of an array of defense-related proteins in plants challenged by phytopathogens. Key mechanisms of this innate immunity system in plants include hypersensitive responses, programmed cell death, and systemic acquired resistance, along with other important mechanisms, including oxidative bursts $(5,28,62)$, the production of phytoalexins and phytohormones $(11,48)$, the regulation of pathogenesis-related (PR) proteins (13, $27,44,49,56-58)$, and synthesis of proteins for cell wall reinforcement $(33,57)$, all of which contribute to retard or inhibit pathogen invasion $(13,44,57)$. In most cases, these defense mechanisms result from the transcriptional activation of an assortment of defense-related genes in planta $(18,28,37,42,61)$.

In recent years, expressed sequence tags (ESTs) from cDNA libraries have been studied in many compatible interactions between pathogens and their hosts $(30,32,60,61)$. A cDNA library can provide molecular resources for analysis of transcribed genes involved in the biological and physiological processes of a pathosystem. These include key information on host-pathogen interactions, host defense mechanisms, resistance and susceptibility, and pathogenicity and virulence. Such libraries are particularly informative where whole genomes have not yet been sequenced, which is the case for both P. sulphurascens and DF. 
To identify and characterize DF defense responses to $P$. sulphurascens infection, we initiated research on molecular aspects of the pathosystem in the late 1990s. Using laboratory-grown DF seedlings inoculated with $P$. sulphurascens and a variety of molecular techniques, we have shown that $P$. sulphurascens can initiate infection of DF seedling roots within 2 days of inoculation and that the host responds by activating many defense-related genes and proteins. Our previous studies have found that there is significant upregulation of several proteins and genes, including a 10.6-kDa antimicrobial peptide, an endochitinase-like protein, a PR10 protein, a thaumatin-like protein (TLP) $(25,51)$ Barwin-like PR2 genes (24), a disease-resistant protein (DRP) (23), and class IV chitinase genes (PR4) (26). In this study, we observed significant upregulation of additional genes which are reported to be involved in plant defense. For example, we report several $R$ genes that encode proteins with a nucleotide-binding site (NBS) and a leucine-rich repeat (LRR) region. This domain architecture is consistent with a role in pathogen recognition and defense response signaling (1). The NBS-LRRs are intracellular receptor proteins that recognize pathogenic effector proteins and activate so-called ETI in plants. In a proteomic study, we also reported an upregulation of an LRR resistance protein in DF infected by $P$. sulphurascens (23). Liu and Ekramoddoullah (31) cloned 67 NBS resistance-gene analogs from western white pine (Pinus monticola Douglas ex. D. Don) using oligonucleotide primers based on the conserved sequence motifs in the NBS domain of angiosperm NBS-LRR genes. Our results, along with others, suggest that a large and diverse NBS-LRR gene family is functional in conifers and playing important roles in defense gene signaling against pathogen attack.

Previously, we recorded significant upregulation of a number of chitinase-like genes and proteins in Phellinus sulphurascens- and A. ostoyae-infected DFs $(25,26,41,51,64)$. The antifungal activity of a class IV chitinase from Picea abies (L.) H. Karst. was tested recently by Ubhayasekera et al. (55), who confirmed that this conifer chitinase strongly inhibits Heterobasidion annosum (Fr.) Bref. sensu lato (s.l.) growth. Another study suggested that wounding and fungal colonization changes chitinase isoforms in Norway spruce (15).

Our ongoing research interest in understanding the Phellinus sulphurascens-DF pathosystem is greatly facilitated by our ability to identify and characterize several DF defense genes identified from a cDNA library that we generated from $P$. sulphurascensinfected DF seedling roots (26); to the best of our knowledge, we are the only group conducting such research. In this article, we profile the expression of a suite of 12 diverse, defense-related genes from roots of $P$. sulphurascens-infected DF seedlings. We also discuss the overall utility of the characterization of the cDNA library in identifying both host and fungal genes with a putative functional role in establishing and maintaining the pathosystem.

\section{MATERIALS AND METHODS}

Plant and fungal materials and inoculation technique. The isolate PFC-581 of $P$. sulphurascens was used to infect DF seedlings. This isolate was collected from the infected stem of a mature DF tree growing near Cowichan Lake on Vancouver Island, BC, Canada. The fungus was initially isolated from DF tissue onto petri plates containing $1.5 \%$ malt extract agar (SigmaAldrich Canada Ltd., Oakville, ON, Canada). Plugs containing $P$. sulphurascens were taken from these cultures and maintained in cryovials with double-distilled water $\left(\mathrm{ddH}_{2} \mathrm{O}\right)$ at $3^{\circ} \mathrm{C}$. These fungal plugs were used to inoculate plates containing $1 \%$ (wt/vol) water agar (Sigma-Aldrich) which were incubated for $\approx 20$ days at room temperature and subsequently used to provide $P$. sulphurascens inoculum for our experiments. Additional cultures of the isolate PFC-581 were preserved in sterile distilled water in cryovials (9).
The coastal DF seed family 60686 used in this study was obtained from the Tree Seed Centre of the British Columbia (BC) Ministry of Forests and Range, Surrey, BC, Canada. To germinate seed, they were treated by first soaking in $\mathrm{ddH}_{2} \mathrm{O}$ for $24 \mathrm{~h}$ and then stratified at $4^{\circ} \mathrm{C}$ for $\approx 21$ days. Following stratification, seed were surface sterilized using $35 \%$ aqueous $\mathrm{H}_{2} \mathrm{O}_{2}$ (vol/vol) for 10 to $12 \mathrm{~min}$ with vigorous agitation and then rinsed at least four times with sterile $\mathrm{H}_{2} \mathrm{O}$. Sterilized seed were placed in petri plates (20 to 25 seeds per plate) containing $1 \%$ (wt/vol) water agar and allowed to germinate in darkness at $24 \pm 1^{\circ} \mathrm{C}$ for 20 to 25 days. Seedlings were aseptically transferred to bipartitioned petri plates, inoculated with $P$. sulphurascens mycelia. $(25,51)$, and incubated in a growth chamber at $20^{\circ} \mathrm{C}$ with a photoperiod of $16 \mathrm{~h}\left(50\right.$ to $\left.60 \mu \mathrm{mol} \mathrm{m}^{-2} \mathrm{~s}^{-1}\right)$.

Construction of cDNA library from roots of $\boldsymbol{P}$. sulphurascens-infected DF seedlings. Total RNA was extracted from entire root systems of $P$. sulphurascens-infected DF seedlings using the Schultz et al. (45) protocol. Three independent RNA extractions per time point that were sampled at 3,5, and 7 days post inoculation (dpi) were pooled together to increase the likelihood of having captured all of the genes in the library that were expressed at each different time point during disease development. A cDNA library was constructed using the Creator SMART cDNA library construction kit (Clontech Laboratories, Inc., Mountain View, CA). Use of this kit allows us to conduct downstream functional analyses. Details on cDNA synthesis and library construction were provided by Islam et al. (26). Briefly, we used $100 \mathrm{ng}$ of total RNA to construct double-stranded cDNA following the manufacturer's instructions. Recombinant pDNR-LIB plasmids containing cDNAs were transformed into Escherichia coli (ElecroMAX DH10B) electrocompetent cells (Invitrogen, Carlsbad, CA). To evaluate the quality of the library, 50 individual cDNA clones were randomly picked and screened using M13 primers (Supplemental Figure 1).

Sequencing of cDNA clones and bioinformatics. In all, 3,600 randomly selected cDNA clones were sent in three separate batches to the BC Cancer Agency's Research Centre, Vancouver, $\mathrm{BC}$, Canada for sequencing. The first, second, and third batches of clone numbers are identified by the prefixes NRC, PFC, and Dfr, respectively. Sequence analysis, alignment, and protein translation of putative genes and bioinformatics of ESTs were conducted as described by Islam et al. (26). After BLASTx search, the ESTs were translated into putative proteins using the ExPASy protein translation tool. We reconfirmed the correct open reading frames of the proteins using BLASTp search. Based on gene annotation analysis of the ESTs using Blast2Go, putative proteins were classified into several functional categories and then nucleotide sequences were submitted to the National Center for Biotechnology Information (NCBI) gene bank.

Quantitative reverse-transcriptase polymerase chain reaction for gene expression analyses. A suite of 12 different genes, which were all quite common in the cDNA library and known to play defense roles in other plants, were selected for expression profiling via quantitative real-time reverse-transcriptase (RT) polymerase chain reaction (qRT-PCR) experiments. These genes putatively encode for PmDefl (defensin), $P m D L P 1$ (dirigent-like protein [DLP]), PmDRP1, PmELP1 (expansin-like protein [ELP]), PmGerm (germin), PmLTP1 (nonspecific lipid-transfer protein [LTP]), PmMLP1 (metallothionein-like protein [MLP]), PmPIP1 (pathogen-induced pepper protein [PIP]), PmPerx (peroxidase), PmTNL1 (toll-interleukin-like receptor-NBS domains [TIR]LRR), PmTLP2, and PmUSP1 (universal stress protein [USP]) (Table 1). qRT-PCR of the 12 genes was conducted as described by Islam et al. (26). Briefly, to amplify fragments of the 12 selected DF defense-related genes, specific primer pairs for each gene were designed using Roche's LightCycler Probe Design Software 2.0 (version 1.0; Roche, Indianapolis, IN). We used PmTubl (DF $\alpha$-tubulin) as an internal reference gene because it was found to be most suitable over the course of study. Expres- 
sion levels of the 12 genes were calculated based on the relative expression of internal reference gene PmTubl (26).

\section{RESULTS}

The cDNA library of $P$. sulphurascens-infected DF seedling roots. We constructed a full-length cDNA library of root tissue of $P$. sulphurascens-infected DF seedlings using the Creator SMART cDNA library construction kit. The primary cDNA library of P. sulphurascens-infected DF seedlings had a titer of $10^{6} \mathrm{CFU} \mathrm{ml}{ }^{-1}$

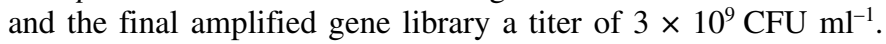
We sequenced a total of 3,600 cDNA randomly selected clones and analyzed the sequence data utilizing relevant software, algorithms, and databases. Our sequence data revealed that $\approx 85 \%$ of the cDNA clones produced sequences of sufficient length to obtain significant matches using BLASTx. Out of these sequences, $>60 \%$ of clones contained the full-length coding region producing predicted mature proteins. In total, 1,637 clones $(48.22 \%)$ were matched with plant genes while 768 clones $(18.59 \%)$ matched with fungal genes. A small percentage of cDNA clones matched with other organisms, including bacteria and lower or higher groups of organisms. We also recorded a considerable number of clones $(14.39 \%)$ that were not matched with any known genes during a BLASTx search (Table 2).

Functional annotation of $P$. sulphurascens-infected DF cDNA clones. The cDNA library generated from $P$. sulphurascens-infected DF seedling roots was used as a source of further genomics and bioinformatics work. In this article, we included only cDNAs that matched with plant genes. We will report on the fungal genes elsewhere. All cDNA clones from the library that were putatively identified from matches to NCBI databases of known functions were classified into general functional categories. The constructed cDNA library includes abundant defenseor stress-related genes, which constitute the highest percentage of cDNA clones $(25 \%)$. Most of the remaining genes belong to other functional groups, including metabolism (15\%), protein synthesis $(13 \%)$, transporters $(6 \%)$, transcription factors $(4.8 \%)$, and energy $(3.8 \%)$. Functional groups with smaller proportions of cDNA

TABLE 1. Quantitative reverse-transcriptase polymerase chain reaction primers for selected Douglas-fir (DF) defense-related genes and three internal reference genes

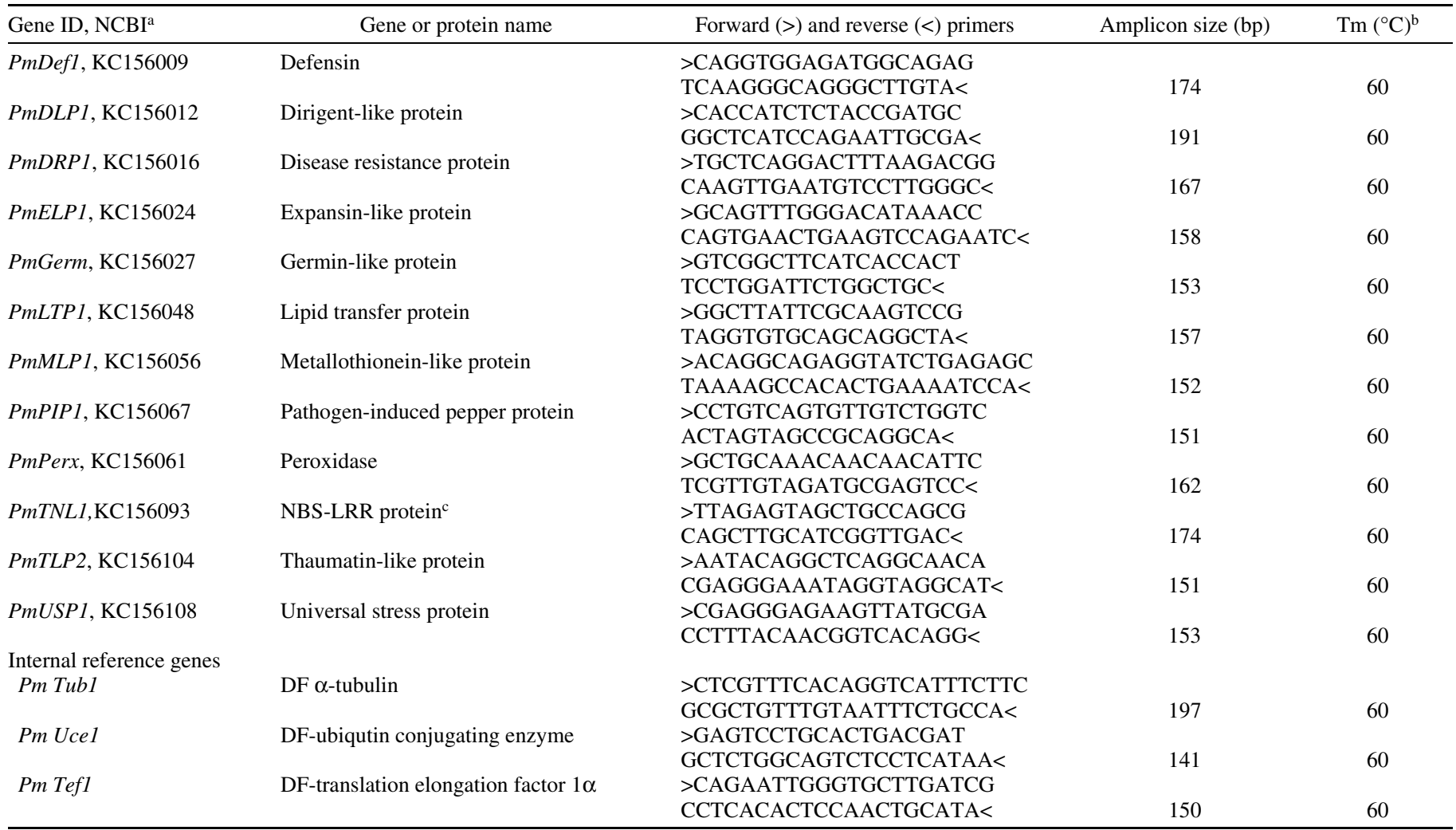

${ }^{a}$ National Center for Biotechnology Information (NCBI) accession numbers.

${ }^{\mathrm{b}}$ Melting temperature.

${ }^{\mathrm{c}}$ NBS-LRR = nucleotide-binding site leucine-rich repeat.

TABLE 2. Summary of sequence data for cDNA clones from Phellinus sulphurascens-infected Douglas-fir seedling roots

\begin{tabular}{|c|c|c|c|c|}
\hline Matching groups or items & Contigs & Singletons & Total & $\%$ \\
\hline Plant & 1,309 & 328 & 1,637 & 48.22 \\
\hline Bacteria & 48 & 19 & 67 & 1.86 \\
\hline Lower groups of organisms (nematode, protozoa, virus) & 22 & 23 & 45 & 1.25 \\
\hline Good quality sequences, unnamed or unmatched & 190 & 328 & 518 & 14.39 \\
\hline Poor quality sequences & 0 & 313 & 313 & 8.69 \\
\hline Vector sequence, no cDNA inserts & 0 & 208 & 208 & 5.78 \\
\hline Redundancy & 1,190 & $\ldots$ & 1,190 & 33.06 \\
\hline
\end{tabular}


clones were secondary metabolism $(3 \%)$, cell structure $(2.3 \%)$, protein destination and storage $(2.1 \%)$, and cell growth or division (1.9\%). We also found a considerable percentage (19\%) of genes that were not assigned to any functional categories (Fig. 1). Sequences of these unclassified cDNAs either matched with hy- pothetical genes of other plants, including rice and Arabidopsis, or did not show any significant matches during a BLASTx search.

Identification and characterization of DF defense-related genes. We identified 130 genes from the cDNA library that could potentially be associated with DF defense responses against

TABLE 3. Putative defense- and/or stress-related genes identified from a cDNA library constructed using Phellinus sulphurascens-infected Douglas-fir seedlings ${ }^{\mathrm{a}}$

\begin{tabular}{|c|c|c|c|c|c|c|}
\hline Genes & $\begin{array}{c}\text { NCBI } \\
\text { number }^{b}\end{array}$ & $\begin{array}{l}\text { DF cDNA clones, } \\
\text { contigs ID }\end{array}$ & bp & Matched species & $\begin{array}{l}\text { Number of } \\
\text { matched }^{\mathrm{c}}\end{array}$ & $E$ value \\
\hline ACC oxidase gene & KC155995 & Contig[2024] & 213 & Picea sitchensis & ABF20552.1 & 0.13 \\
\hline Adenosine kinase 2 gene & KC155996 & PFC018.C21_C07 & $258 *$ & Oryza sativa & ABR25519.1 & $2.00 \mathrm{E}-39$ \\
\hline Antimicrobial peptide 1 (AMP2) gene & KC155997 & Contig[0228] & 322 & Pinus sylvestris & AAL05052 & $3.00 \mathrm{E}-24$ \\
\hline$\beta-1,3$-Glucananse gene & KC155998 & Contig[0802] & $502 *$ & Musa acuminata & AAB 82772.2 & $6.00 \mathrm{E}-68$ \\
\hline CAD1 (constitutively activated cell death 1 ) gene & KC155999 & PFC014.C21.1_F02 & $531^{*}$ & Arabidopsis thaliana & NP_564333.1 & $6.00 \mathrm{E}-69$ \\
\hline Calcium-binding EF hand family gene & KC156000 & Contig[1769] & 507 & Arabidopsis thaliana & NP_173499.1 & 0.17 \\
\hline Calcium-binding pollen allergen (CBPA) gene & KC156001 & PFC0110.C21.1_H08 & 360 & Arachis hypogaea & AAZ20284.1 & $6.00 \mathrm{E}-18$ \\
\hline Carbonic anhydrase family gene & KC156002 & PFC0110.C21.1_D12 & 489 & Arabidopsis thaliana & NP_200444.1 & $1.00 \mathrm{E}-30$ \\
\hline$\beta$-Fructofuranosidase; Cell wall invertase gene & KC156003 & Contig $[0840]$ & $426^{*}$ & Pisum sativum & AAC 17166.1 & $1.00 \mathrm{E}-36$ \\
\hline Ascorbate peroxidase (Chloroplast) gene & KC156004 & PFC017.C21_A01 & $246^{*}$ & Nelumbo nucifera & $* *$ & $* *$ \\
\hline Class II Chitinase Pm Chi2-1 & GU063812 & PFC0111.C21 B02 & 717 & Pseudotsuga menziesii & $* *$ & $* *$ \\
\hline Class II Chitinase Pm Chi2-2 & GU063813 & PFC014.C21.1 D02 & 696 & Pseudotsuga menziesii & $* *$ & $* *$ \\
\hline Class II Chitinase Pm Chi2-3 & GU063814 & Contig[340] & 717 & Pseudotsuga menziesii & $* *$ & $* *$ \\
\hline Class IV chitinase Pm Chi-1 & GU063815 & Contig $[0014]$ & 831 & Pseudotsuga menziesii & $* *$ & $* *$ \\
\hline Class IV chitinase Pm Chi-2 & GU063816 & Contig[0569] & 816 & Pseudotsuga menziesii & $* *$ & $* *$ \\
\hline Class IV chitinase Pm Chi-3 & GU063817 & PFC016.C21_E05 & $503^{*}$ & Pseudotsuga menziesii & $* *$ & $* *$ \\
\hline Class IV chitinase Pm Chi-4 & GU063818 & Contig[1034] & 834 & Pseudotsuga menziesii & $* *$ & $* *$ \\
\hline Class IV chitinase Pm Chi-5 & GU063819 & Contig[1287] & 546 & Pseudotsuga menziesii & $* *$ & $* *$ \\
\hline Class IV chitinase Pm Chi-6 & GU063820 & Contig[0191] & 510 & Pseudotsuga menziesii & $* *$ & $* *$ \\
\hline Copper chaperone gene & KC156005 & Dfr026.C21_G15 & 237 & Populus alba & AAT12488.1 & $1.00 \mathrm{E}-27$ \\
\hline Cysteine proteinase inhibitor gene 1 & KC156006 & Contig[1259] & 423 & Glycine max & BAA19608.1 & $1.00 \mathrm{E}-55$ \\
\hline Cysteine proteinase inhibitor gene & KC156007 & Contig[0756] & 696 & Glycine $\max$ & BAA19608.1 & $1.00 \mathrm{E}-30$ \\
\hline Defensin gene 1 & KC156008 & PFC0111.C21_F04 & 252 & Pinus sylvestris & ABO61348.1 & $2.00 \mathrm{E}-38$ \\
\hline Defensin gene 2 & KC156009 & Contig[0168] & 255 & Pinus sylvestris & ABO61348 & $1.00 \mathrm{E}-23$ \\
\hline Defensin gene 3 & KC156010 & PFC011.C21.1_C01 & $216^{*}$ & Pinus sylvestris & ABO61348.1 & $2.00 \mathrm{E}-14$ \\
\hline Defensin 4 , putative ( $\gamma$ thionine) gene & KC156011 & Contig $[1850]$ & 255 & Picea abies & CAA62761.1 & $2.00 \mathrm{E}-30$ \\
\hline Dirigent gene 1 & KC156012 & Contig[1247] & 615 & Picea spp. & ABD52124.1 & $1.00 \mathrm{E}-88$ \\
\hline Dirigent gene 2 & KC156013 & Contig[1017] & 675 & Picea glauca & ABD52129.1 & $9.00 \mathrm{E}-94$ \\
\hline Dirigent gene 3 & KC156014 & Contig[1459] & 595 & Picea engelmannii spp. & ABD52113.1 & $6.00 \mathrm{E}-95$ \\
\hline Dirigent-like gene4 & KC156015 & Contig[0297] & 561 & Picea engelmannii & ABD52115 & $8.00 \mathrm{E}-87$ \\
\hline Disease resistance gene1 & KC156016 & Contig[1101] & $568 *$ & Pinus sylvestris & AAR36911.1 & $1.00 \mathrm{E}-04$ \\
\hline Disease resistance gene2 & KC156017 & Contig $[0775]$ & $777 *$ & Lycopersicon esculentum & AAC78593.1 & $2.00 \mathrm{E}-51$ \\
\hline Disease-resistant-related gene3 & KC156018 & Contig[1919] & 411 & Oryza sativa & AAL78367.1 & $3.00 \mathrm{E}-68$ \\
\hline EDGP precursor (Nectarine precursor) gene & KC156019 & PFC0111.C21_F10 & $318^{*}$ & Daucus carota & BAA03413.1 & $4.00 \mathrm{E}-18$ \\
\hline Elicitor-inducible gene EIG-J7 gene & KC156020 & PFC016.C21_B05 & 228 & Capsicum аппиит & AAR83862.1 & $4.00 \mathrm{E}-55$ \\
\hline Emb1624 (embryo defective 1624) gene & KC156021 & Contig $[0688]$ & $741^{*}$ & Arabidopsis thaliana & NP_191121.1 & $5.00 \mathrm{E}-64$ \\
\hline Emb1624 (embryo defective 1624) gene & KC156022 & Contig $[0224]$ & $756^{*}$ & Arabidopsis thaliana & NP_191121 & $1.00 \mathrm{E}-11$ \\
\hline Enhanced disease susceptibility gene 1 & KC156023 & PFC0111.C21_H03 & $597 *$ & Vitis vinifera & ABU43059.1 & $3.00 \mathrm{E}-29$ \\
\hline Expansin-like gene & KC156024 & PFC011.C21.1_B05 & $528 *$ & Cunninghamia lanceolata & ABM69039.1 & $2.00 \mathrm{E}-45$ \\
\hline Expansin-like precursor gene & KC156025 & Dfr026.C21_B08 & $552 *$ & Arabidopsis thaliana & NP_193436.2 & $2.00 \mathrm{e}-33$ \\
\hline Germin-like gene 1 & KC156026 & Contig $[0895]$ & 498 & Picea abies & AAV31746.1 & $5.00 \mathrm{E}-73$ \\
\hline Germin-like gene 2 & KC156027 & PFC013.C21.1_C09 & 675 & Picea abies & AAV31746.1 & $2.00 \mathrm{E}-57$ \\
\hline Germin-like gene3 & KC156028 & Dfr021.C21_L09 & 672 & Picea abies & AAV31746.1 & $8.00 \mathrm{E}-73$ \\
\hline Glutathione peroxidase gene & KC156029 & Dfr022.C21_O20 & 513 & Nelumbo nucifera & ABN46985.1 & $6.00 \mathrm{E}-67$ \\
\hline Glycoprotein induced gene & KC156030 & Dfr021.C21_J02 & 405 & Bromus inermis & BAD22765.1 & $5.00 \mathrm{E}-55$ \\
\hline Glycoprotein-like gene & KC156031 & Contig[0122] & 405 & Solanum tuberosum & ABA40467 & $4.00 \mathrm{E}-53$ \\
\hline Glycosyl hydrolase family 5 gene & KC156032 & NRC053.C21_O05 & $741^{*}$ & Arabidopsis thaliana & NP_172772.2 & $3.00 \mathrm{E}-40$ \\
\hline Harpin induced gene 1 homolog gene & KC156033 & Contig[0716] & $372 *$ & Oryza sativa & AAB97367.1 & $1.00 \mathrm{E}-13$ \\
\hline Heat shock factor binding gene 1 & KC156034 & Contig $[0857]$ & 273 & Zea mays & AAR18070.1 & $7.00 \mathrm{E}-16$ \\
\hline Heat shock factor binding gene 2 & KC156035 & PFC0110.C21.1_G12 & 258 & Zea mays & AAM15929.1 & $2.00 \mathrm{E}-13$ \\
\hline Heat shock gene 17.0 & KC156036 & Contig $[0962]$ & 459 & Picea glauca & AAB01561.1 & $3.00 \mathrm{E}-54$ \\
\hline Heat shock gene 70 & KC156037 & PFC014.C21.1_C03 & $813^{*}$ & Gossypium hirsutum & ACJ11742.1 & 3.00E-107 \\
\hline Heat shock gene 90 & KC156038 & Contig $[0057]$ & $636^{*}$ & Nicotiana tabacum & BAE97400 & $3.00 \mathrm{E}-89$ \\
\hline Heat shock protein binding gene & KC156039 & PFC013.C21.1_D11 & 384 & Arabidopsis thaliana & NP_564175.2 & $6.00 \mathrm{E}-17$ \\
\hline Heat shock protein binding / unfolded gene & KC156040 & Contig $[1248]$ & $363^{*}$ & Arabidopsis thaliana & NP_564175.2 & $5.00 \mathrm{E}-17$ \\
\hline Histone $\mathrm{H} 2 \mathrm{AX}$ gene & KC156041 & Contig[0239] & 423 & Picea abies & P35063 & $2.00 \mathrm{E}-36$ \\
\hline Histone H3.2 gene & KC156042 & Contig[1130] & 411 & Arabidopsis thaliana & NP_001078516.1 & $5.00 \mathrm{E}-70$ \\
\hline Histone $\mathrm{H} 4$ gene & KC156043 & Contig[1264] & 312 & Hyacinthus orientalis & АAT08725.1 & $7.00 \mathrm{E}-38$ \\
\hline HR-like lesion-inducer family gene & KC156044 & Contig[1184] & 471 & Oryza sativa & ABY52930.1 & $1.00 \mathrm{E}-26$ \\
\hline HSP like gene & KC156045 & Dfr023.C21_I01 & $786^{*}$ & Arabidopsis thaliana & BAF01805.1 & $2.00 \mathrm{E}-67$ \\
\hline Leucine rich gene & KC156046 & Contig $[0016]$ & $822 *$ & Arachis hypogaea & ABH09321 & $1.10 \mathrm{E}-02$ \\
\hline \multirow[t]{2}{*}{ Leucine-rich repeat family gene / extensin family } & KC156047 & PFC014.C21.1_E03 & $636^{*}$ & Arabidopsis thaliana & NP_189091.1 & $9.00 \mathrm{E}-51$ \\
\hline & & & & & \multicolumn{2}{|c|}{ (continued on next page) } \\
\hline
\end{tabular}

a Asterisks: $*=$ partial sequences are available, $* *=$ reported by Islam et al. (26), and $* * *=$ reported by Islam et al. (24).

b National Center for Biotechnology Information (NCBI) accession number.

c NCBI accession of the matched species. 
pathogens or other stressors. Although 61 of these genes were singletons, the other 69 were assembled into contigs containing multiple clones (Table 3). Out of these defense- or stress-related genes, those coding for $\approx 19$ proteins or protein families were most common to the cDNA library, which included the following: antimicrobial peptide, Barwin-type PR-4 (PR4), chitinase (PR3), defensin (PR12), DLP, DRP, ELP, germin (oxalate oxidase; PR15), glucanase (PR2), heat-shock protein, histone, intracellular PR protein family 10 (PR10), LTP, MLP, PIP, peroxidase (PR9), proteinase inhibitors (PR6), TLPs (PR5), and TIR-LRR.

TABLE 3. (continued from preceding page)

\begin{tabular}{|c|c|c|c|c|c|c|}
\hline Genes & $\begin{array}{c}\text { NCBI } \\
\text { number }^{b}\end{array}$ & $\begin{array}{l}\text { DF cDNA clones, } \\
\text { contigs ID }\end{array}$ & $\mathrm{bp}$ & Matched species & $\begin{array}{l}\text { Number of } \\
\text { matched }^{\mathrm{c}}\end{array}$ & $E$ value \\
\hline Lipid transfer gene & KC156048 & Contig[1293] & 384 & Avicennia marina & AAK01293.1 & $5.00 \mathrm{E}-15$ \\
\hline Lipoxygenase gene 1 & KC156049 & Contig[1620] & $801 *$ & Zea mays & AF149803_1 & $2.00 \mathrm{E}-86$ \\
\hline Lipoxygenase gene2 & KC156050 & Dfr023.C21_D07 & 411 & Fragaria $\times$ ananassa & CAE17327.1 & $1.00 \mathrm{E}-32$ \\
\hline Lipoxygenase gene 3 & KC156051 & Dfr023.C21_I07 & $822 *$ & Corylus avellana & CAD10740.1 & $1.00 \mathrm{E}-88$ \\
\hline Lipoxygenase gene- 5 & KC156052 & Dfr026.C21_O01 & $522 *$ & Physcomitrella patens & ABF66651.1 & $2.00 \mathrm{E}-31$ \\
\hline Macrophage migration inhibitory factor gene & KC156053 & PFC019.C21.1_A07 & 405 & Oryza sativa & ABG22330.1 & $3.00 \mathrm{E}-35$ \\
\hline MAP3K-like protein kinase gene & KC156054 & PFC018.C21_E04 & $324 *$ & Arabidopsis thaliana & BAD95429.1 & $5.00 \mathrm{E}-17$ \\
\hline MATE efflux family gene & KC156055 & Dfr021.C21_H16 & $384 *$ & Arabidopsis thaliana & NP_567640.1 & $7.00 \mathrm{E}-36$ \\
\hline Metallothionein-like gene & KC156056 & Contig $[0151]$ & $243 *$ & Picea sitchensis & ABK21547.1 & $2.00 \mathrm{E}-27$ \\
\hline Nonspecific lipid transfer-like gene 1 & KC156057 & Contig[1276] & 420 & Prosopis juliflora & ABF06565.1 & $4.00 \mathrm{E}-04$ \\
\hline Nonspecific lipid-transfer gene 2 & KC156058 & Contig[0813] & 384 & Lens culinaris & AAX35808 & $5.00 \mathrm{E}-24$ \\
\hline Nonsymbiotic hemoglobin gene & KC156059 & Contig[0901] & $789 *$ & Alnus firma & BAE75956.1 & $2.00 \mathrm{E}-55$ \\
\hline Pathogenesis-related protein 4 type & JQ064520 & Contig $[0308]$ & 444 & Pseudotsuga menziesii & $* * *$ & $* * *$ \\
\hline Pathogenesis-related protein 4 type & JQ064523 & Contig[309] & 444 & Pseudotsuga menziesii & $* * *$ & $* * *$ \\
\hline Pathogenesis-related protein $4 \mathrm{~b}$ & JQ064526 & Contig[0262] & 429 & Pseudotsuga menziesii & $* * *$ & $* * *$ \\
\hline PDR8/PEN3 (Pleiotropic drug resistance 8) gene & KC156060 & PFC019.C21.1_D03 & $732 *$ & Arabidopsis thaliana & NP_176196.1 & $9.00 \mathrm{E}-56$ \\
\hline Peroxidase gene 1 & KC156061 & Contig $[0658]$ & $837 *$ & Picea abies & CAH10840.1 & $5.00 \mathrm{E}-87$ \\
\hline Peroxidase gene 2 & KC156062 & Contig $[0710]$ & 537 & Picea abies & CAH10842.1 & $1.00 \mathrm{E}-93$ \\
\hline Ascorbate Peroxidase gene 2 & KC156063 & Contig[0753] & 387 & Picea abies & CAH10840.1 & $2.00 \mathrm{E}-110$ \\
\hline Peroxidase gene 3 & KC156064 & Contig[1905 & $279^{*}$ & Picea abies & CAD92856.1 & $3.00 \mathrm{E}-31$ \\
\hline Peroxiredoxin gene & KC156065 & Dfr025.C21_H05 & $297 *$ & Phaseolus vulgaris & CAC17803.1 & $2.00 \mathrm{E}-45$ \\
\hline Phytoalexin-deficient 4-2 gene & KC156066 & Dfr023.C21_L05 & $765^{*}$ & Solanum tuberosum & AAW82884.1 & $4.00 \mathrm{E}-30$ \\
\hline Pip1 (pathogen induced pepper gene) gene & KC156067 & PFC013.C21.1_D01 & $636^{*}$ & Capsicum annuиm & ABF72432.1 & $5.00 \mathrm{E}-46$ \\
\hline Pollen allergen CJP38 gene 1 & KC156068 & Contig $[0100]$ & $600 *$ & Cryptomeria japonica & BAD93486.1 & $7.00 \mathrm{E}-29$ \\
\hline Pollen allergen CJP38 gene 2 & KC156069 & Dfr026.C21_H10 & $765^{*}$ & Cryptomeria japonica & BAD93486.1 & $2.00 \mathrm{E}-64$ \\
\hline Pollen-specific protein gene 3 & KC156070 & Dfr026.C21_B11 & $273^{*}$ & Hyacinthus orientalis & AAT08700.1 & $3.00 \mathrm{E}-07$ \\
\hline PR10 gene1 & KC156071 & Contig[1154] & 489 & Pinus monticola & AAL49999.1 & $2.00 \mathrm{E}-57$ \\
\hline PR10 gene2 & KC156072 & Contig[0027] & 486 & Pinus monticola & AAL50006 & $1.00 \mathrm{E}-25$ \\
\hline Probable glutathione S-transferase gene1 & KC156073 & Contig[0393] & 330 & Picea mariana & AAC32139.1 & $2.00 \mathrm{E}-100$ \\
\hline Probable glutathione S-transferase gene2 & KC156074 & Dfr022.C21_K05 & 720 & Picea mariana & AAC32139.1 & $3.00 \mathrm{E}-99$ \\
\hline Glutathione S-transferase gene & KC156075 & Dfr024.C21_L04 & 723 & Picea mariana & AAC32139.1 & $1.00 \mathrm{E}-94$ \\
\hline Profilin gene & KC156076 & PFC015.C21_C07 & 399 & Cucumis melo & CAN70308.1 & $1.00 \mathrm{E}-48$ \\
\hline Protein kinase gene & KC156077 & PFC014.C21.1_B12 & $249 *$ & Medicago truncatula & ABE91930.1 & $1.00 \mathrm{E}-38$ \\
\hline Zinc binding protein kinase $\mathrm{C}$ inhibitor gene & KC156078 & PFC011.C21.1_G06 & 393 & Zea mays & NP_001105498.1 & $2.00 \mathrm{E}-48$ \\
\hline Protein kinase, $\mathrm{CK} 2$ regulatory subunit 2 gene & KC156079 & NRC053.C21_M12 & $489 *$ & Nicotiana tabacum & CAD32500.1 & $2.00 \mathrm{E}-42$ \\
\hline Protein kinase CK2, $\alpha$-subunit gene & KC156080 & Dfr023.C21_O15 & $618^{*}$ & Zea mays & CAA72362.1 & $1.00 \mathrm{E}-61$ \\
\hline Protein kinase family gene & KC156081 & Contig[1393] & $723 *$ & Arabidopsis thaliana & NP_192429.1 & $8.00 \mathrm{E}-26$ \\
\hline Putative Mob1/phocein family gene & KC156082 & Contig[0568] & $363^{*}$ & Oryza sativa & AAT76373.1 & $3.00 \mathrm{E}-60$ \\
\hline Putative 11-zinc finger gene & KC156083 & Contig[0737] & 639 & Arabidopsis thaliana & BAD94400.1 & $1.00 \mathrm{E}-08$ \\
\hline Putative allergen Cup a 4 gene & KC156084 & Dfr022.CR_L24 & 576 & Cupressus arizonica & ABP87672.1 & $1.00 \mathrm{E}-36$ \\
\hline Putative allergen like gene & KC156085 & Contig[0257] & 306 & Cupressus arizonica & ABP87672 & $3.00 \mathrm{E}-36$ \\
\hline Putative brown plant hopper-induced resistance (BPHS) gene & KC156086 & Contig[1745] & $303^{*}$ & Oryza sativa & BAD21528.1 & $2.00 \mathrm{E}-14$ \\
\hline Putative calmodulin gene & KC156087 & PFC0111.C21_F12 & 450 & Cryptomeria japonica & BAF31994.1 & $2.00 \mathrm{E}-68$ \\
\hline Putative class IV chitinase gene & KC156088 & Contig $[0269]$ & 501 & Picea abies & AAT09426 & $3.00 \mathrm{E}-74$ \\
\hline Putative heat shock $81-2$ gene & KC156089 & Dfr022.C21_F10 & $528^{*}$ & Arabidopsis thaliana & AAN31859.1 & $2.00 \mathrm{E}-62$ \\
\hline Putative histone $\mathrm{H} 4$ gene & KC156090 & Contig[0601] & 426 & Pinus pinaster & CAC84679.1 & $2.00 \mathrm{E}-42$ \\
\hline Putative intracellular pathogenesis-related gene; PR10 & KC156091 & Contig $[0958]$ & 486 & Picea glauca & AAF12810.1 & $4.00 \mathrm{E}-51$ \\
\hline Putative peroxidase gene & KC156092 & Contig[0043] & 1002 & Solanum tuberosum & CAC42086 & $6.00 \mathrm{E}-121$ \\
\hline Putative TIR-NBS type R gene & KC156093 & Contig[0909] & 501 & Malus $\times$ domestica & AAQ93077.1 & 0.16 \\
\hline Putative uclacyanin gene 3 & KC156094 & Contig $[0820]$ & $540 *$ & Oryza sativa & BAD24983.1 & $4.00 \mathrm{E}-20$ \\
\hline Receptor like protein gene 1 & KC156095 & Dfr026.C21_E17 & 756 & Phaseolus vulgaris & $\mathrm{CAO} 24173.1$ & $7.00 \mathrm{E}-26$ \\
\hline Receptor protein kinase-related gene 2 & KC156096 & Dfr025.C21_E06 & $792 *$ & Arabidopsis thaliana & NP_566697.1 & $5.00 \mathrm{E}-21$ \\
\hline Serine/threonine kinase gene & KC156097 & PFC012.C21.1_C06 & $306^{*}$ & Sorghum bicolor & CAA73068.1 & $4.00 \mathrm{E}-53$ \\
\hline Receptor like serine/threonine kinase gene & KC156098 & Dfr026.C21_G04 & 729 & Zea mays & ACG28478.1 & $6.00 \mathrm{E}-17$ \\
\hline Small heat-shock chaperone gene & KC156099 & Dfr024.C21_A17 & 594 & Pseudotsuga menziesii & CAC81964.1 & $1.00 \mathrm{E}-57$ \\
\hline Snakin2 gene & KC156100 & Contig[0707] & 330 & Solanum tuberosum & CAC44012.1 & $7.00 \mathrm{E}-20$ \\
\hline Snakin-like cysteine rich gene & KC156101 & NRC053.C21_M07 & 327 & Phaseolus vulgaris & CAJ43591.1 & $2.00 \mathrm{E}-19$ \\
\hline Tau class glutathione S-transferase gene1 & KC156102 & Dfr023.C21_D04 & 732 & Picea mariana & AAC32139.1 & $1.00 \mathrm{E}-92$ \\
\hline Tau class glutathione S-transferase gene2 & KC156103 & Dfr025.C21_E09 & 711 & Pinus tabuliformis & AAY64044.1 & $2.00 \mathrm{E}-84$ \\
\hline Thaumatin-like gene 1 & KC156104 & Contig $[0147]$ & $390 *$ & Pinus monticola & AAS 85755 & $2.00 \mathrm{E}-37$ \\
\hline Thaumatin-like gene 2 & KC156105 & PFC019.C21.1_B02 & $309^{*}$ & Pinus monticola & AAS85755.1 & $4.00 \mathrm{E}-56$ \\
\hline TIR/P-loop/LRR gene & KC156106 & Contig $[1005]$ & $276^{*}$ & Pinus taeda & AAM28914.1 & $9.00 \mathrm{E}-09$ \\
\hline WRKY transcription factor gene & KC156107 & PFC011.C21.1_C10 & 375 & Oryza sativa & DAA05124.1 & $1.00 \mathrm{E}-19$ \\
\hline Wound-induced stress gene & KC156108 & Contig $[0079]$ & $231^{*}$ & Phaseolus vulgaris & Q09020 & $1.00 \mathrm{E}-05$ \\
\hline Xyloglucan endotransglycosylase gene 1 & KC156109 & PFC011.C21.1_A01 & 594 & Litchi chinensis & ABK30787.1 & $2.00 \mathrm{E}-40$ \\
\hline Xyloglucan endotransglycosylase precursor gene2 & KC156110 & Contig $[0006]$ & 831 & Populus tremula & $\mathrm{gb} \mid \mathrm{ABL} 75361$ & $8.00 \mathrm{E}-91$ \\
\hline Xyloglucan galactosyltransferase gene 3 & KC156111 & Contig[1258] & $249 *$ & Solanum tuberosum & AAM22687.1 & $2.00 \mathrm{E}-12$ \\
\hline Xyloglucan:xyloglucosyl transferase gene4 & KC156112 & Dfr026.CR.1_D18 & $327 *$ & Arabidopsis thaliana & NP_181224.1 & $2.00 \mathrm{E}-23$ \\
\hline
\end{tabular}


Expression analyses of selected defense-related genes. Multiple copies of ESTs of several genes or gene families were obtained from the cDNA library of infected DF roots, indicating their potential involvement in DF defense responses against fungal infection. qRT-PCR of the 12 genes we selected to profile (PmDefl, PmDLP1, PmDRP1, PmELP1, PmGerm, PmLTP1, PmMLP1, PmPIP1, PmPerx, PmTNL1, PmTLP2, and PmUSP1) revealed that, following inoculation and infection of DF roots by $P$. sulphurascens, expression of these genes increased significantly from their basal expression levels (Fig. 2). In general, there was a significant increase in expression of selected DF defense genes after $P$. sulphurascens infection. However, the timing of the peak expression level varied for each gene over the course of infection. In all cases, a significant increase in expression occurred within $12 \mathrm{~h}$ post inoculation (hpi). The highest expression for PmDef1, PmELP1, and PmLTP1 was at 2 dpi whereas, for PmDLP1, PmGerm, PmMLP1, and PmTNL1, it was at $3 \mathrm{dpi}$; for $P m P I P 1$, it was at $5 \mathrm{dpi}$; and for PmDRP1, PmPerx, PmTLP2, and PmUSP 1 , it was at 7 dpi. PmDefl, PmDLP1, PmGerm, $P m E L P 1$, and PmTNL1 expression levels were considerably reduced at 7 dpi relative to their expression at 2 or 3 dpi (Fig. 2).

We compared variation in expression between controls and $P$. sulphurascens-infected DF seedling roots by calculating the fold changes of the transcript levels of these genes and found that the highest fold change for each gene varied over the course of infection (Table 4). For example, the highest fold changes recorded at 12 hpi were for PmDLPl (20.30; $P=0.00)$, PmPerx (14.70; $P=0.0)$, PmTNL1 (11.50; $P=0.00)$, and PmUSP1 (7.70; $P=0.00)$. The highest fold changes recorded at $2 \mathrm{dpi}$ were for PmDefl (5.00; $P=0.00)$, PmELPl (12.30; $P=0.00)$, and PmLTP1 (3.08; $P=0.00)$. PmGerm, PmMLP1, and PmPIPl, with values of $12.07(P=0.00), 9.67(P=0.00)$, and $15.92(P=0.00)$, respectively, had the highest fold changes at $3 \mathrm{dpi}$. At $7 \mathrm{dpi}$, PmDRP1 and PmTLP2 had the highest fold change values of 5.13 $(P=0.0)$ and $15.89(P=0.00)$, respectively.

Putative fungal PR genes. Our cDNA library also yielded transcripts with significant homology to fungal genes, which were presumed to originate from $P$. sulphurascens (Table 5). Excluding genes encoding ribosomal proteins, $18.8 \%$ of the fungal genes were involved in energy-related physiological activities; $17 \%$ were involved in protein fate; $14.7 \%$ were metabolism-related; $10 \%$ were involved in protein synthesis; $7.8 \%$ were involved in cell rescue, disease, and virulence; $5 \%$ were involved in cellular communication; and $3.7 \%$ were plant cell-wall-degrading enzymes. We identified genes putatively involved in patho- genicity from this library as well as from a pure $P$. sulphurascens cDNA library based on a search of the relevant literature $(\mathrm{H}$. L. Williams, R. N. Sturrock, M. A. Islam, C. Hammett, A. K. M. Ekramoddoullah, and I. Leal, unpublished data).

Preliminary qRT-PCR data ((H. L. Williams, R. N. Sturrock, M. A. Islam, C. Hammett, A. K. M. Ekramoddoullah, and I. Leal, unpublished data) indicate significant upregulation of several of these fungal genes during infection of DF roots, including the cell-wall-degrading enzymes endoglucanases, expansins, and an O-glucosyl hydrolase. Also, a glutathione S-transferase, a peroxidase, heat-shock proteins, cytochrome $\mathrm{P} 450$ proteins, an arsenate reductase, and several hydrophobin coding genes were found to be upregulated immediately after infection. In most cases, increased expression levels were detected during the first 2 to 3 days postinfection.

\section{DISCUSSION}

The cDNA library of $P$. sulphurascens-infected DF seedlings. Our results confirm that the constructed cDNA library is a useful resource from which to identify and characterize genes associated with DF defense responses. From a total of 3,600 cDNA clones, we identified 132 DF defense- or stress-related genes. Although our sequence data could be more robust, they do provide insights into DF defense mechanisms at a molecular level. The technology we used in this study for full-length cDNA enrichment is vigorous and only requires $<1 \mu \mathrm{g}$ of starting total RNA. Isolated, independent clones can be directly transferred to the expression vector for further gene expression and functional analyses. The amplified cDNA fragments were 700 to $2,000 \mathrm{bp}$ and $\approx 90 \%$ of insertion fragments were $>1 \mathrm{~kb}$ in size, suggesting that the insertion fragments harbored most of the mRNAs and met the requirements for further studies on gene structure, gene transcription, gene expression, and protein translation $(42,43)$.

Initially, we assessed the quality of the library through a smallscale sequencing of cDNA clones. This technique has been found to be a quick and efficient approach to assess library quality $(36,46)$. Our preliminary data confirmed that many of the identified DF genes have been reported to be induced in biotic or abiotic stress conditions in planta; hence, the constructed cDNA library is a valuable resource for further molecular studies of the DF-P. sulphurascens pathosystem. The presence of many fungal genes in the cDNA library and our previous data suggested that the host tissues were successfully colonized and infected by the fungus $(3,30,32,60)$, which allowed us to con-

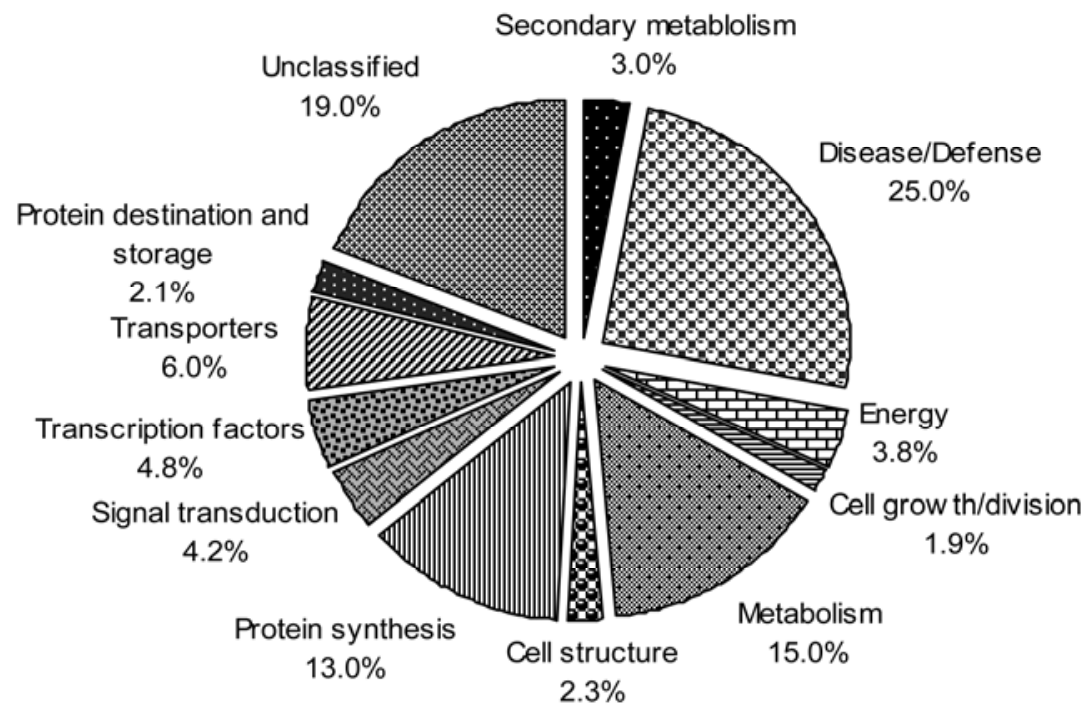

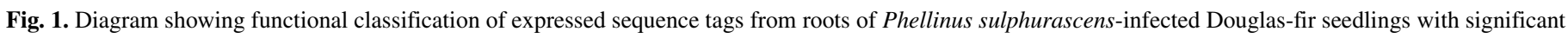
similarities to plant genes available in GenBank. The putative genes were classified into 12 functional categories according to Bevan et al. (4). 
duct molecular studies on both host and pathogen in a laboratory environment.

Functional annotations of the DF cDNA clones. Although the cDNA library we constructed from $P$. sulphurascens-infected DF roots contained mostly plant and fungal genes, a few cDNA clones matched with bacteria and other groups of organisms, and a considerable number of clones (19\%) were considered unclassified. These unclassified ESTs did not match with any

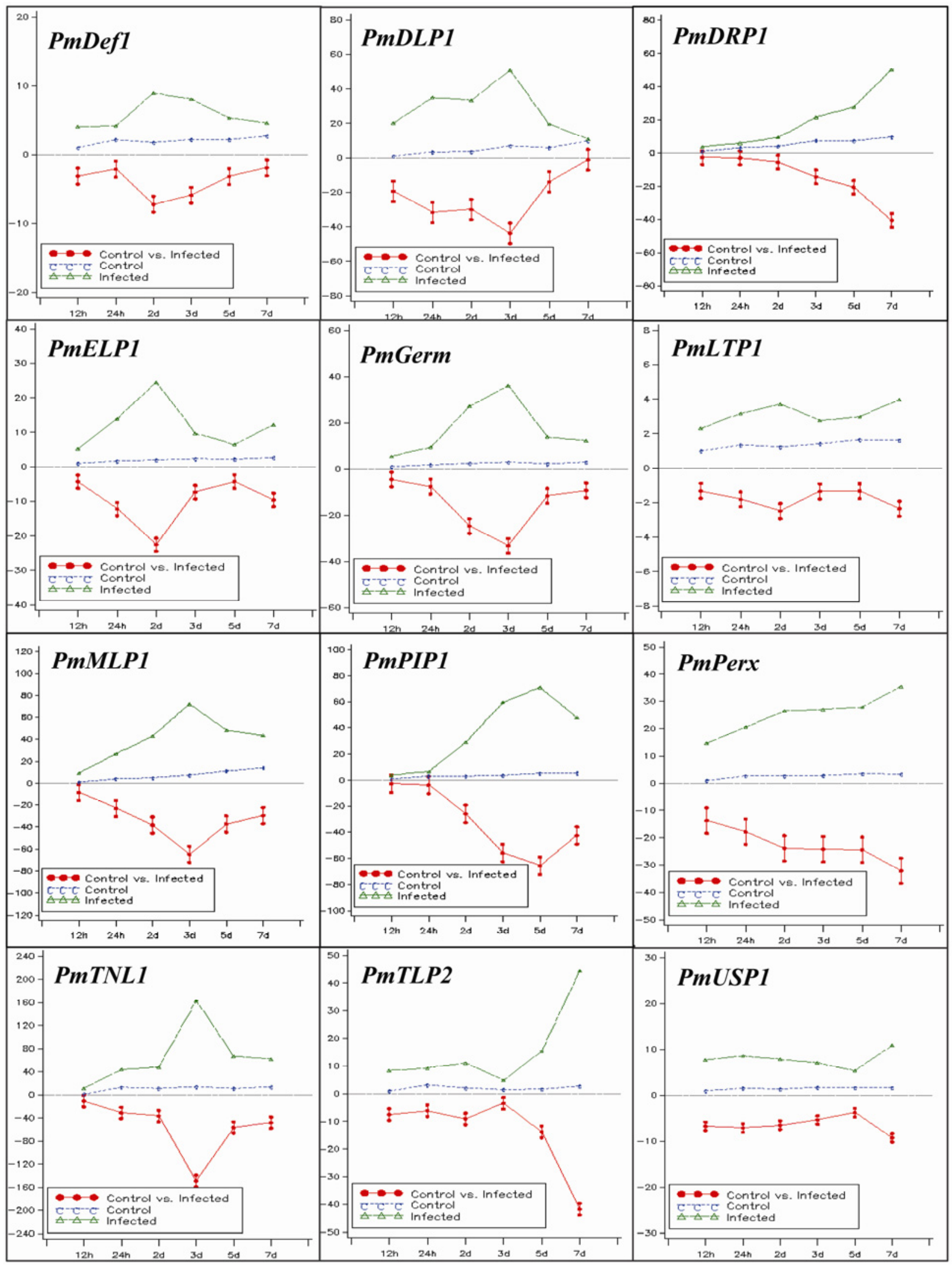

Fig. 2. Relative expression profiles over 7 days for selected defense genes in roots of Douglas-fir seedlings infected with Phellinus sulphurascens. Quantitative reverse-transcriptase polymerase chain reaction data analysis was based on comparative crossing threshold values of the amplicons (Y-axis) over the time course (X-axis). Gene names are shown above their corresponding graphs. 
functional categories in the protein database although, in some cases, this lack of homology may have been due to sequences being derived from the $5^{\prime}$ nontranslated region of the cDNA (47). Many of the unclassified ESTs occurred repeatedly in the library, which may signify their involvement in DF defense mechanisms. Additional work is required to identify these unclassified ESTs.

Functional annotations of $\boldsymbol{P}$. sulphurascens cDNA clones. Occurrence of fungal genes coding for cell-degrading enzymes, carbohydrate metabolism, energy-related proteins, and pathogenesis- or stress-related proteins in the library suggests that $P$. sulphurascens establishes a pathogenic condition very rapidly after infection. Our results suggest that $P$. sulphurascens establishes and colonizes DF root tissue through a number of PR genes that are expressed significantly within 2 dpi. Previously, we reported that the presence of mycelia inside host epidermal cells by $3 \mathrm{dpi}$ and their extensive colonization in host cortical tissues by $7 \mathrm{dpi}$ significantly altered gene expression and protein accumulation in host tissues (51). The early events of $P$. sulphurascens infection of DF seedling roots, including adhesion of hyphae to the root surface, formation of appressoria-like structures, and penetration of host tissues by hyphal tips, were described elsewhere $(25,51)$. The present study documented a number of fungal candidate genes for further detailed study to understand the molecular interactions of $P$. sulphurascens during infection of DF host tissue.

Putative DF defense- or stress-related genes. Our cDNA library sequence data further confirmed that multiple defense gene families are active in DF seedlings infected by $P$. sulphurascens.

TABLE 4. Gene expression (fold changes) of selected defense-related genes in Phellinus sulphurascens-infected Douglas-fir root tissues over the course of infection ${ }^{\mathrm{a}}$

\begin{tabular}{|c|c|c|c|c|c|c|}
\hline \multirow[b]{2}{*}{ Gene ID } & \multicolumn{6}{|c|}{ Fold change over time $(P)$} \\
\hline & $12 \mathrm{hpi}$ & 24 hpi & 2 dpi & 3 dpi & 5 dpi & 7 dpi \\
\hline PmDef1 & 4.10 & 1.91 & 5.00 & 3.68 & 2.42 & 2.09 \\
\hline PmDLP1 & 20.30 & 10.26 & 9.54 & 7.24 & 3.38 & $1.11(0.70)$ \\
\hline PmELP1 & 5.30 & 8.18 & 12.30 & 4.04 & 2.95 & 4.55 \\
\hline PmGerm & 5.50 & 5.22 & 10.88 & 12.07 & 6.04 & 4.07 \\
\hline PmnLTP1 & 2.30 & 2.28 & 3.08 & 2.00 & 1.76 & 2.50 \\
\hline PmTNL1 & 11.50 & 3.34 & 4.27 & 11.40 & 6.02 & 4.42 \\
\hline PmTLP2 & 8.40 & 2.91 & 5.33 & 3.26 & 9.06 & 15.89 \\
\hline PmUSP1 & 7.70 & 5.37 & 5.64 & 4.18 & 3.37 & 6.81 \\
\hline
\end{tabular}

${ }^{a}$ Fold change values were obtained from quantitative reverse-transcriptase polymerase chain reaction expression data (crossing threshold values) analyzed by SAS PROC GLM repeated-measures analysis of variance; hpi = hours postinoculation and dpi = days postinoculation. $P$ values obtained from differences between control and $P$. sulphurascens-infected samples. $P=0.00$ in all cases except for $P m D L P 1$ at 7 dpi.

TABLE 5. Selected putative fungal pathogenesis- or stress-related genes identified from a cDNA library constructed using Phellinus sulphurascens-infected Douglas-fir seedlings

\begin{tabular}{|c|c|c|c|}
\hline Putative fungal genes & GenBank accession & Organism & $E$ value \\
\hline \multicolumn{4}{|l|}{ Cell wall degradation (extracellular metabolism) } \\
\hline GH family 61 protein (endoglucanase IV) & JK317035 & Schizophyllum commune & $2 \mathrm{e}-111$ \\
\hline Endoglucanase (GH family 5) & JK316759 & Polyporus arcularius & $3 e-101$ \\
\hline O-glucosyl hydrolase, predicted (GH family 53) & JO317810 & Schizosaccharomyces pombe & $6 e-18$ \\
\hline Polysaccharide deacetylase & JO317784 & Postia placenta & $5 e-178$ \\
\hline Expansin family protein & JO317783 & Laccaria bicolor & $8 \mathrm{e}-43$ \\
\hline \multicolumn{4}{|l|}{ Cell rescue, disease, and virulence } \\
\hline Glutaredoxin & JK316410 & Cryptococcus gattii & $8 \mathrm{e}-33$ \\
\hline Thioredoxin & JK316317 & Aspergillus flavus & $6 e-41$ \\
\hline Thioredoxin II & JK316341 & Candida tropicalis & $3 e-34$ \\
\hline Heat shock protein Hsp90 & JO317786 & Laccaria bicolor & $2 \mathrm{e}-121$ \\
\hline Heat-shock protein 90 & JO317787 & Schizophyllum commune & $1 e-111$ \\
\hline Heat shock protein 90 & JK316346 & Coprinopsis cinerea & $2 \mathrm{e}-28$ \\
\hline Heat shock protein & JK317117 & Coprinopsis cinerea & $9 \mathrm{e}-30$ \\
\hline Cytochrome P450 & JK316391 & Postia placenta & $5 e-66$ \\
\hline Cytochrome P450 & JK317118 & Lentinula edodes & $4 e-36$ \\
\hline Lipase & JO317791 & Taiwanofungus camphoratus & $3 e-126$ \\
\hline Lipase & JK316329 & Taiwanofungus camphoratus & $2 e-24$ \\
\hline \multicolumn{4}{|l|}{ Protein fate (folding, modification, destination) } \\
\hline Metalloprotease & JO317767 & Coprinopsis cinerea & $2 \mathrm{e}-89$ \\
\hline \multicolumn{4}{|l|}{ Cellular communication/signal transduction mechanism } \\
\hline Hypothetical adenylyl cyclase associated protein & JK316409 & Postia placenta & $1 \mathrm{e}-25$ \\
\hline \multicolumn{4}{|c|}{ Cell type differentiation (sporulation, fruiting body formation) } \\
\hline Hydrophobin-315 & JK317027 & Pholiota nameko & $6 e-32$ \\
\hline Hydrophobin 2 & JK316976 & Heterobasidion annosum & $2 e-29$ \\
\hline Hydrophobin 1 & JK316997 & Serpula lacrymans & $6 e-33$ \\
\hline
\end{tabular}


These genes constituted the largest functional group of the library and included genes encoding antimicrobial peptides, Barwin-like PR4, chitinases (PR3), defensins (PR12), DRPs, heat-shock proteins, histones, leucine-rich proteins, lipoxigenase, MLPs (PR13), nonspecific LTPs (PR14), proteinase inhibitors (PR6), peroxidases (PR9), PR protein family 10 (ribonuclease-type; PR10), snakins, TIR/P-loop/LRR, a TLP (PR5), WRKY transcription factors, and xyloglucanases (PR2). It is remarkable that a number of defense-related genes matched with previously reported DF proteins that are upregulated after $P$. sulphurascens infection including protein kinase, DRP, heat-shock proteins, peroxidase, class IV chitinase, and TIR/P-loop/LRR protein (23). These data suggest that multiple defense gene or protein families are involved in early defense in DF. Under a compatible pathosystem, these defense genes enhance host capability to protect or to limit subsequent infections (44). It is suggested that conifers exhibit both local and systemic induction of defense genes, regulated either constitutively or induced by chemicals or pathogens (6). Our results and other data reported to date suggest that a large and diverse NBS-LRR gene family may be functional in conifers and playing important roles in defense gene signaling against pathogen attack. For example, the NBS-LRRs recognize pathogenic effector proteins and activate an ETI system in plants $(54,65,66)$. The receptor kinase coding genes identified from our library most likely activate a PTI system in DF after recognizing pathogens. Upon fungal infection, DF receptor kinases or kinase-like proteins may initiate chitin-triggered immunity in DF to recognize $P$. sulphurascens. This response eventually may activate a large set of antifungal or defense-related protein coding genes or gene families, including antimicrobial peptides, Barwin-like genes (PR4), chitinases (PR3), germins, glucanases (PR2), heat-shock proteins, intracellular-PR protein (PR10), peroxidases, and TLPs (PR5). We also identified a few genes that are involved in cell wall reinforcement, which include DLPs, expansins, and LTPs.

Interestingly, we also recorded a number of low-molecular weight antimicrobial peptide (AMP)-coding genes that were activated in the roots of $P$. sulphurascens-infected DFs. These genes code for DF AMPs, defensins/thionins, nonspecific LTPs, and also include snakin-like protein coding genes. AMPs contain even numbers of cysteines which are connected pairwise by disulfide bridges, thus providing high stability to the peptides $(7,40)$. We previously reported that a $10.6-\mathrm{kDa}$ AMP significantly increased in DF roots relative to controls after inoculation with $P$. sulphurascens $(26,51)$ is localized in the extracellular space of host root tissues and also is in close contact with $P$. sulphurascens inside these tissues (26). Some of our recent data suggest that this AMP inhibits growth of several pathogenic fungi in vitro (M. A. Islam, H. L. Williams, and R. N. Rona, unpublished data). Antimicrobial peptides have been found to be active in other pathosystems involving conifers $(2,14,16)$.

Expressions of DF defense genes. Expression results for the suite of 12 diverse genes we profiled by qRT-PCR paralleled those from our previous studies. The frequent occurrence of these selected defense genes in the cDNA library and their significant increased expression after pathogen attack suggest that they play direct or indirect roles in DF defense. Recognition of pathogenic molecular patterns or effectors (pathogenic proteins) results in the upregulation of an array of defense-related proteins through activation of signal transduction and transcription genes such as WRKY and other transcription factors. Although we have identified a large set of defense genes and compared expression patterns, further studies are needed to determine the specific roles of these genes and the proteins. Our results clearly showed that the selected genes were significantly upregulated after $P$. sulphurascens infection. Many of these genes have been found to be upregulated in other conifer systems $(16,17,34,38,39)$.

Comparisons between average gene expression of control and P. sulphurascens-infected roots over the course of infection suggest that different defense genes have different degrees of temporal or spatial specificity (22). Such differences are possibly due to a synergistic role by defense genes where multiple gene families are actively involved to enhance multi-level defenses. To discover more about DF defense genes, we recently conducted transcriptome analyses using RNAseq of roots of DF seedlings challenged by a variety of stressors; we will report on results of these analyses elsewhere.

Finally, our data also suggest that both acidic and basic protein coding genes from multiple defense gene families are activated in DF after pathogen attack. It is most likely that the coordinate induction of multiple defense pathways is dependent from different signal molecules such as ethylene, salicylic acid (SA), and methyl jasmonate (63), which are triggered by the $P$. sulphurascens within 12 hpi. Previous studies confirm that SA predominantly induces the PR genes coding for acidic PR proteins, whereas both ethylene and jasmonic acid induce mostly the expression of PR genes coding the basic PR isoforms $(37,53)$. Thus, it is most likely that DF defense genes are induced by more than one signal molecule following $P$. sulphurascens infection because we have identified both acidic and basic protein-coding genes.

In summary, we have successfully isolated high-integrity RNA and constructed a full-length cDNA library using $P$. sulphurascensinfected DF seedling roots. Our cDNA library provides new insights into DF transcriptional responses during pathogen challenge and serves as a foundation for functional analysis of candidate defense-related genes. qRT-PCR data showed that defense genes are significantly increased after pathogen challenge and are differentially expressed over time. It is also evident that several multigene families, actively involved in DF defense, synergistically play defense roles upon $P$. sulphurascens infection. Our future work will focus on precise functional analyses of candidate defense genes of DF using recombinant protein expression technology.

\section{ACKNOWLEDGMENTS}

This work was funded, in part, by Natural Resources Canada, Canadian Forest Service, Forest Biotechnology/Genomics Initiative funds to R. N. Sturrock. We thank H. Williams, K. Pellow, and A. Zamany for their technical and scientific support; and K. Quazi, Associate Director, Quintiles Canada Inc., Quebec, Canada for his assistance with statistical analyses of gene expression data.

\section{LITERATURE CITED}

1. Ameline-Torregrosa, C., Wang, B.-B., O’Bleness, M. S., Deshpande, S., Zhu, H., Roe, B., Young, N. D., and Cannon, S. B. 2008. Identification and characterization of nucleotide-binding site-leucine-rich repeat genes in the model plant Medicago truncatula. Plant Physiol. 146:5-21.

2. Asiegbu, F. O., Choi, W., Li, G., Nahalkova, J., and Dean, R. A. 2003. Isolation of a novel antimicrobial peptide gene (Sp-AMP) homologue from Pinus sylvestris (Scots pine) following infection with the root rot fungus Heterobasidion annosum. FEMS Microbiol. Lett. 228:27-31.

3. Bernardo, A., Bai, G., Guo, P., Xiao, K., Guenzi, A. C., and Ayoubi, P. 2007. Fusarium graminearum-induced changes in gene expression between Fusarium head blight-resistant and susceptible wheat cultivars Funct. Integr. Genomics 7:69-77.

4. Bloomberg, W. J., and Reynolds, G. 1985. Growth loss and mortality in laminated root rot infection centers in second-growth Douglas-fir on Vancouver Island. For. Sci. 31:497-508.

5. Bolwell, G. P., Bindschedler, L. V., Blee, K. A., Butt, V. S., Davies, D. R., Gardner, S. L., Gerrish, C., and Minibayeva, F. 2002. The apoplastic oxidative burst in response to biotic stress in plants: a three-component system. J. Exp. Bot. 53:1367-1376.

6. Bonello, P., Gordon, T. R., Herms, D. A., Wood, D. L., and Erbilgin, N. 2006. Nature and ecological implications of pathogen-induced systemic resistance in conifers: A novel hypothesis. Physiol. Mol. Plant Pathol. 68:97-106.

7. Broekaert, W. F., Cammue, P. A., De Bolle, M., Thevissen, K., Samblanx, G., and Osborn, R. 1997. Antimicrobial peptides from plants. Crit. Rev. Plant Sci. 16:297-323. 
8. Buckland, D. C., Molnar, A. C., and Wallis, G. W. 1954. Yellow laminated root rot of Douglas fir. Can. J. Bot. 32:69-81.

9. Burdsall, Jr., H. H., and Dorworth, E. B. 1994. Preserving cultures of wood-decaying Basidiomycotina using sterile distilled water in cryovials. Mycologia 86:275-280.

10. Cruickshank, M. G., Jaquish, B., Nemec, and A. F. L. 2010. Resistance of half-sib interior Douglas-fir families to Armillaria ostoyae in British Columbia following artificial inoculation. Can. J. For. Res. 40:155-166.

11. Dixon, D. P., Lapthorn, A., and Edwards, R. 2002. Plant glutathione transferases. Genomics Biol. (Rev.) 3:3004.1-3004.10.

12. Dodds, P. N., and Rathjen, J. P. 2010. Plant immunity: Towards an integrated view of plant-pathogen interactions. Nat. Rev. Genet. 11:539-548.

13. Edreva, A. 2005. Pathogenesis-related proteins: research progress in the last 15 years. Gen. Appl. Plant Physiol. 31:105-124.

14. Ekramoddoullah, A. K. M., Liu, J.-J., and Zamani, A. 2006. Cloning and characterization of a putative antifungal peptide gene $(P m-A M P 1)$ in Pinus monticola. Phytopathology 96:164-170.

15. Fossdal, C. G., Hietala, A. M., Kvaalen, H., and Solheim, H. 2006. Changes in host chitinase isoforms in relation to wounding and colonization by Heterobasidion annosum: Early and strong defense response in 33-year-old resistant Norway spruce clone. Tree Physiol. 26:169-177.

16. Fossdal, C. G., Nagy, N. E., Sharma, P., and Lönneborg, A. 2003. The putative gymnosperm plant defensin polypeptide (SPI1) accumulates after seed germination, is not readily released, and the SPI1 levels are reduced in Pythium dimorphum-infected spruce roots. Plant Mol. Biol. 52:291302.

17. Fossdal, C. G., Sharma, P., and Lönneborg, A. 2001. Isolation of the first putative peroxidase cDNA from a conifer and the local and systemic accumulation of related proteins upon pathogen infection. Plant. Mol. Biol. 47:423-435.

18. Fritig, B., Heitz, T., and Legrand, M. 1998. Antimicrobial proteins in induced plant defense. Curr. Opin. Immunol. 10:16-22.

19. Goheen, D. J., and Hansen, E. M. 1993. Effects of pathogens and bark beetles on forests. Pages 175-196 in: Beetle-Pathogen Interactions in Conifer Forests. T. B. Schowalter and G. M. Filip, eds. Academic Press, London.

20. González, J., Reyes, F., Salas, C., Santiago, M., Codriansky, Y., Coliheuque, N., and Silva, H. 2006. Arabidopsis thaliana: a model host plant to study plant-pathogen interaction using Chilean field isolates of Botrytis cinerea. Biol. Res. 39:221-228.

21. Gururani, M. A., Venkatesh, J., Upadhyaya, C. P., Nookaraju, A., Pandey, S. K., and Park, S. W. Plant disease resistance genes: current status and future directions. Physiol. Mol. Plant Pathol. 78:51-65.

22. Hietala, A. M., Kvaalen, H., Schmidt, A., Jøhnk, N., Solheim, H., and Fossdal, C. G. 2004. Temporal and spatial profiles of chitinase expression by Norway spruce in response to bark colonization by Heterobasidion annosum. Appl. Environ. Microbiol. 70:3948-3953.

23. Islam, M. A., Sturrock, R. N., and Ekramoddoullah, A. K. M. 2008. A proteomics approach to identify proteins differentially expressed in Douglas-fir seedlings infected by Phellinus sulphurascens. J. Proteomics 71:425-438.

24. Islam, M. A., Sturrock R. N., and Ekramoddoullah A. K. M. 2011. Molecular cloning and gene transcription analyses of Barwin-type PR-4 genes from Phellinus sulphurascens-infected Douglas-fir seedlings. For. Pathol. 42:279-288.

25. Islam, M. A., Sturrock, R. N., Holmes, T. A., and Ekramoddoullah, A. K. M. 2009. Ultrastructural studies of Phellinus sulphurascens infection of Douglas-fir roots and immunolocalization of host pathogenesis-related proteins. Mycol. Res. 113:700-712.

26. Islam, M. A., Sturrock, R. N., Williams, H. L., and Ekramoddoullah, A. K. M. 2010. Identification, characterization, and expression analyses of class II and IV chitinase genes from Douglas-fir seedlings infected by Phellinus sulphurascens. Phytopathology 100:356-366.

27. Jøhnk, N., Hietala, A. M., Fossdal, C. G., Collinge, D. B., and Newman, M. A. 2005. Defense-related genes expressed in Norway spruce roots after infection with the root rot pathogen Ceratobasidium bicorne (anamorph: Rhizoctonia sp.). Tree Physiol. 25:1533-1543.

28. Kombrink, E., and Somssich, I. E. 1995. Defense responses of plants to pathogens. Adv. Bot. Res. 21:1-34

29. Lamb, C., and Dixon, R. A. 1997. The oxidative burst in plant disease resistance. Annu. Rev. Plant Physiol. Plant Mol. Biol. 48:251-275.

30. Lawton, M. A., and Lamb, C. J. 1987. Transcriptional activation of plant defense genes by fungal elicitor, wounding, and infection. Mol. Cell. Biol. 7:335-341.

31. Liu, J.-J., and Ekramoddoullah, A. K. M. 2003. Isolation, genetic variation and expression of TIR-NBS-LRR resistance gene analogs from western white pine (Pinus monticola Dougl. ex. D. Don.). Mol. Genet. Genomics 270:432-441.

32. Ma, J., Huang, X., Wang, X., Chen, X., Qu, Z., Huang, L., and Kang, Z. 2009. Identification of expressed genes during compatible interaction be- tween stripe rust (Puccinia striiformis) and wheat using a cDNA library. BMC Genomics 10:586.

33. Mandal, S., and Mitra, A. 2007. Reinforcement of cell wall in roots of Lycopersicon esculentum through induction of phenolic compounds and lignin by elicitors Physiol. Mol. Plant Pathol. 71:201-209.

34. Nagy, N. E., Fossdal, C. G., Dalen, L. S., Lönneborg, A., Heldal, I. M., and Johnsen, Ø. 2004. Effects of Rhizoctonia infection and drought on peroxidase and chitinase activity in Norway spruce (Picea abies). Physiol. Plant. 120:465-473.

35. Nelson, E. E., and Sturrock, R. N. 1993. Susceptibility of western conifers to laminated root rot (Phellinus weirii) in Oregon and British Columbia field tests. West. J. Appl. For. 8:67-70.

36. Peterson, L. A., Brown, M. R., Carlisle, A. J., Kohn, E. C., Liotta, L. A., Emmert-Buck, M. R., and Krizman, D. B. 1998. An improved method for construction of directionally cloned cDNA libraries from microdissected cells. Cancer Res. 58:5326-5328.

37. Pieterse, C. M. J., and Van Loon, L. C. 1999. Salicylic acid-independent plant defence pathways. Trends Plant Sci. 4:52-58.

38. Pirttilä, A. M., Laukkanen, H., and Hohtola, A. 2002. Chitinase production in pine callus (Pinus sylvestris L.): A defence reaction against endophytes? Planta 214:848-852.

39. Ralph, S., Park, J. Y., Bohlmann, J., Mansfield, S. D. 2006. Dirigent proteins in conifer defense: Gene discovery, phylogeny, and differential wound- and insect-induced expression of a family of DIR and DIR-like genes in spruce (Picea spp.). Plant Mol. Biol. 60:21-40.

40. Rivillas-Acevedo, L., and Soriano-García, M. 2007. Antifungal activity of a protean extract from Amaranthus hypochondriacus seeds. J. Mex. Chem. Soc. 51:136-140.

41. Robinson, R. M., Sturrock, R. N., Davidson, J. J., Ekramoddoullah, A. K. M., and Morrison, D. J. 2000. Detection of chitinase-like protein in the roots of Douglas-fir trees infected with Armillaria ostoyae and Phellinus weirii. Tree Physiol. 20:493-502.

42. Rushton, P. J., and Somssich, I. E. 1998. Transcriptional control of plant genes responsive to pathogens. Curr. Opin. Plant Biol. 1:311-315.

43. Sambrook, J., and Russell, D. W. 2001. Molecular Cloning: A Laboratory Manual, 3rd ed. Cold Spring Harbor Laboratory, Cold Spring Harbor, NY.

44. Scherer, N. M., Thompson, C. E., Freitas, L. B., Bonatto, S. L., and Salzano, F. M. 2006. Evolutionary analysis in pathogenesis-related proteins. NIC Workshop 2006, NIC Ser. 34:193-196.

45. Schultz, D. J., Craig, R., Cox-Foster, D. L., Mumma, R. O., and Medford, J. O. 1994. RNA isolation from recalcitrant plant tissue. Plant Mol. Biol. Rep. 12:310-316.

46. Skiba, B., Ford, R., and Pang, E. C. K. 2005. Construction of a cDNA library of Lathyrus sativus inoculated with Mycosphaerella pinodes and the expression of potential defence-related expressed sequence tags (ESTs). Physiol. Mol. Plant Pathol. 66:55-67.

47. Skinner, W., Keon, J., and Hargreaves, J. 2001. Gene information for fungal plant pathogens from expressed sequences. Curr. Opin. Microbiol. 4:381-386.

48. Sobolev, V. S., Guo, B. Z., Holbrook, C. C., and Lynch, R.E. 2007. Interrelationship of phytoalexin production and disease resistance in selected peanut genotypes. J. Agric. Food Chem. 55:2195-2200.

49. Stintzi, A., Heitz, T., Prasad, V., Widemann-Merdinoglu, S., Kauffmann, S., Geoffroy, P., Legrand, M., and Fritig, B. 1993. Plant 'pathogenesis related' proteins and their role in defense against pathogens. Biochemie 75:687-706.

50. Sturrock, R. 2005. Investigations of Douglas-fir resistance to Phellinus weirii. TICtalk 6:3-7, a Publication of the Forest Genetics Council of British Columbia. http://www.fgcouncil.bc.ca/tictalk-jun05-web.pdf

51. Sturrock, R. N., Islam, M. A., and Ekramoddoullah, A. K. M. 2007. Host pathogen interactions in Douglas-fir seedlings infected by Phellinus sulphurascens. Phytopathology 97:1406-1414.

52. Thies, W. G., and Sturrock, R. N. 1995. Laminated root rot in western North America. Gen. Tech. Rep. PNW-GTR-349. United States Department of Agriculture, Portland, OR.

53. Thomma, B. P. H. J., Eggermont, K., Penninckx, I. A. M. A., MauchMani, B., Vogelsang, R., Cammue, B. P. A., and Broekaert, W. F. 1998. Separate jasmonate-dependent and salicylate-dependent defense-response pathways in Arabidopsis are essential for resistance to distinct microbial pathogens. Proc. Natl. Acad. Sci. USA 95:15107-15111.

54. Thomma, B. P. H. J., Nürnberger, T., and Joostena, M. H. A. J. 2011. Of PAMPs and effectors: the blurred PTI-ETI dichotomy. Plant Cell 23:4-15.

55. Ubhayasekera, W., Rawat, R., Ho, S. W. T., Wiweger, M., von Arnold, S., Chye, M.-L., and Mowbray, S. L. 2009. The first crystal structures of a family 19 class IV chitinase: the enzyme from Norway spruce. Plant Mol. Biol. 71:277-289.

56. van Loon, L. C. 1985. Pathogenesis-related proteins. Plant Mol. Biol. 4:111-116.

57. van Loon, L. C., Rep, M., and Pieterse, C. M. J. 2006. Significance of inducible defense-related proteins in infected plants. Annu. Rev. 
Phytopathol. 44:135-162.

58. van Loon, L. C., and van Strien, E. A. 1999. The families of pathogenesisrelated proteins, their activities, and comparative analysis of PR-1 type proteins. Physiol. Mol. Plant Pathol. 55:85-97.

59. Wallis, G. W., and Reynolds, G., 1965. The initiation and spread of Poria weirii root rot of Douglas-fir. Can. J. Bot. 43:1-9.

60. Wang, S. M., Fears, S. C., Zhang, L., Chen, J.-J., and Rowley, J. D. 2000. Screening poly(dA/dT)-cDNAs for gene identification. Proc. Natl. Acad. Sci. USA 97:4162-4167.

61. Wise, R. P., Moscou, M. J., Bogdanove, A. J., and Whitham, S. A. 2007. Transcript profiling in host-pathogen interactions. Annu. Rev. Phytopathol. 45:329-369.

62. Wojtaszek, P. 1997. Oxidative burst: An early plant response to pathogen infection. Biochem. J. 322:681-692.
63. Xu, Y., Chang, P. F. L., Liu, D., Narasimhan, M. L., Raghothama, K. G., Hasegawa, P. M., and Bressan, R. A. 1994. Plant defense genes are synergistically induced by ethylene and methyl jasmonate. Plant Cell 6:10771085.

64. Zamani, A., Sturrock, R. N., Ekramoddoullah, A. K. M., Wiseman, S. B., and Griffith, M. 2003. Endochitinase activity in the apoplastic fluid of Phellinus weirii-infected Douglas-fir and its association with over wintering and antifreeze activity. For. Pathol. 33:299-316.

65. Zhang, J., Lu, H., Li, X. Li, Y., Cui, H. Wen, C.-K., Tang, X., Su, Z., and Zhou, J.-M. 2010. Effector-triggered and pathogen-associated molecular pattern-triggered immunity differentially contribute to basal resistance to Pseudomonas syringae. Mol. Plant-Microbe Interact. 23:940-948.

66. Zipfel, C. 2009. Early molecular events in PAMP-triggered immunity. Curr. Opin. Plant Biol. 12:414-420. 